\title{
Morphometrical analysis of urothelial cells in voided urine of patients with low grade and high grade bladder tumours
}

\author{
ECM OOMS, PJH KURVER, ${ }^{*}$ MATHILDE E BOON* \\ From the Institute of Pathology, Free University Hospital, Amsterdam, and the *Department of Pathology, \\ Stichting Samenwerking Delftse Ziekenhuizen, Delft, The Netherlands
}

SUMMARY The morphometric differences between the urothelial cells (wet-fixed Papanicolaoustained) in the voided urine of 20 patients with low grade and high grade bladder tumours were measured. The morphometrical data of this learning set resulted in a cytomorphometrical classification rule, which was applied to a test set of 21 cases with low grade and high grade bladder tumours.

The results of the cytomorphometrical classification rule correspond very well with the histomorphometrical classification and the histological grade of the parent tumours.

The results indicate that it is feasible to classify bladder tumours using the cytomorphometrical data of the exfoliated urothelial cells alone.

In a previous study ${ }^{1}$ it was shown that cellular and nuclear dimensions of urothelial cells in the voided urine of patients with grade I and grade II tumours differ, and that normal urothelial cells cannot be distinguished from cells exfoliated from grade I tumours. However, it was not possible to separate all grade I tumours from all grade II tumours. For therapeutic reasons it is important to discriminate between these low grade bladder tumours (grade I and II) and high grade (grade III) tumours; it is clinically less important to separate grade I and II tumours. $^{2}{ }^{3}$ An objective method of distinguishing low grade from high grade tumours is desirable.

For the classification rule (learning set) were used: mean nuclear area, mean nuclear diameter, standard deviation nuclear area, mean nuclear/cytoplasm $(\mathrm{N} / \mathrm{C})$ area ratio, mean $\mathrm{N} / \mathrm{C}$ diameter ratio, standard deviation N/C area ratio and mean cytoplasmic area.

\section{Material and methods}

\section{LEARNING SET}

Twenty cases of bladder tumour were selected for the learning set: 10 patients with a low grade tumour (grade I and II) and 10 cases with a high grade bladder tumour (grade III).
All these patients belong to a reference set of bladder tumours, in which there is no doubt about the histological grade. ${ }^{10}$

\section{TEST SET}

The test set consisted of 21 cases, of which voided urine and the transurethrally resected bladder tumour were available for this study.

\section{HISTOMORPHOMETRY}

The parent tumours of the test set were histomorphometrically classified using a classification rule. For this classification the nuclear areas of the superficial cells are measured. ${ }^{10}$

\section{CYTOLOGICAL MATERIAL}

Voided urine was used for this study. Two consecutive samples were taken from each patient and the smears with the highest cytological grading were used. Wet-fixed Papanicolaou-stained smears were used for this study. The wet-fixation was achieved by spray-fixing (coating fixative $80 \mathrm{ml}$ polyethylene glycol (MW 300), $690 \mathrm{ml}$ isopropanol, $170 \mathrm{ml}$ acetone, $60 \mathrm{ml}$ distilled water). ${ }^{5}$

\section{CYTOMORPHOMETRY}

In each smear, 50 urothelial cells were measured. Except for the exclusion of cells with degenerative features, cells were selected at random. The 
Table 1 Descriptive statistics and significant differences between wet-fixed Papanicolaou-stained cells in low grade bladder and high grade tumours in the learning set

\begin{tabular}{|c|c|c|c|}
\hline Parameter (mean) & Low grade & High grade & $\begin{array}{l}\text { Probability } \\
\text { of difference } \\
\text { (two sided) }\end{array}$ \\
\hline $\begin{array}{l}\text { Mean nuclear perimeter }(\mu \mathrm{m}) \\
\text { Standard deviation mean nuclear perimeter }(\mu \mathrm{m}) \\
\text { Mean nuclear area }\left(\mu \mathrm{m}^{2}\right) \\
\text { Standard deviation mean nuclear area }\left(\mu \mathrm{m}^{2}\right) \\
\text { Mean nuclear diameter }(\mu \mathrm{m}) \\
\text { Standard deviation mean nuclear diameter }(\mu \mathrm{m}) \\
\text { Mean } N / C \text { area ratio } \\
\text { Mean } N / C \text { diameter ratio }\end{array}$ & $\begin{array}{r}37 \cdot 5 \\
6 \cdot 2 \\
76 \cdot 6 \\
25 \cdot 3 \\
9 \cdot 6 \\
1 \cdot 5 \\
0 \cdot 51 \\
0 \cdot 71\end{array}$ & $\begin{array}{r}43 \cdot 5 \\
8 \cdot 6 \\
107 \cdot 8 \\
44 \cdot( \\
11 \cdot 4 \\
2 \cdot 2 \\
0.58 \\
0.76\end{array}$ & $\begin{array}{r}<0 \cdot(01 \\
0 \cdot 03 \\
<0 \cdot(01 \\
<0 \cdot(01 \\
0 \cdot(01 \\
\quad 0 \cdot(02 \\
<0 \cdot 01 \\
<(0 \cdot() 1\end{array}$ \\
\hline
\end{tabular}

Table 2 Cytomorphometrical and histomorphometrical classification

\begin{tabular}{|c|c|c|c|}
\hline Case & $\begin{array}{l}\text { Morphometry- } \\
\text { histology } \\
\text { probability to be } \\
\text { low grade }\end{array}$ & $\begin{array}{l}\text { Histological } \\
\text { grade } \\
\text { (WHO) }\end{array}$ & $\begin{array}{l}\text { Morphometry- } \\
\text { cytology } \\
\text { probability to be } \\
\text { low grade }\end{array}$ \\
\hline 1 & 0.05 & 3 & 0.07 \\
\hline 2 & $1 \cdot 00$ & 1 & 0.99 \\
\hline 3 & 0.99 & 3 & 0.12 \\
\hline 4 & $1 \cdot 00$ & 2 & 0.99 \\
\hline 5 & $1 \cdot 00$ & 2 & 0.95 \\
\hline 6 & 0.99 & 2 & 0.71 \\
\hline 7 & $0 \cdot 06$ & 3 & ()$\cdot 02$ \\
\hline 8 & ()$\cdot 01$ & 3 & 0.38 \\
\hline 9 & ()$\cdot 23$ & 3 & $0 \cdot 01$ \\
\hline 10 & 0.98 & 2 & 0.98 \\
\hline 11 & $1 \cdot 00$ & 2 & 0.99 \\
\hline 12 & 0.98 & 2 & 0.96 \\
\hline 13 & 0.01 & 3 & 0.14 \\
\hline 14 & $1 \cdot 00$ & 2 & 0.93 \\
\hline 15 & $1 \cdot 00$ & 2 & $1 \cdot 00$ \\
\hline 16 & $(0 \cdot 04$ & 3 & 0.46 \\
\hline 17 & 0.05 & 3 & 0.01 \\
\hline 18 & $0 \cdot(00)$ & 3 & 0.07 \\
\hline 19 & 0.99 & 2 & 0.47 \\
\hline 20 & ()$\cdot 00$ & 3 & ()$\cdot 02$ \\
\hline 21 & 0.99 & 2 & 0.96 \\
\hline
\end{tabular}

measurements were performed with a graphic tablet (ASM, Leitz, West-Germany), equipped with a camera lucida system. The cursor could be seen through the camera lucida drawing tube, and the contour of the nuclei and cells outlined.

The computer calculated the following features irom the two delineated areas: nuclear perimeter, sell perimeter, nuclear area, cell area, nuclear diameter $\left(2 \vee \frac{\text { area }}{\pi}\right)$, cell diameter, N/C area ratio, $\mathrm{N}: \mathrm{C}$ diameter ratio. From each slide the mean and the standard deviation of the assessed features were calculated. This gave 16 sets of values per case.

\section{STATISTICAL ANALYSIS}

Statistical analysis was carried out on a PDP $11 \mathrm{com}$ puter DEC with part of the program STP (statistical package) developed by one of us (PHJK).

The descriptive statistics of the measurements in the wet-fixed Papanicolaou-stained smears were computed for the two groups (low grade $v$ high grade).

Wilcoxon's test was used to establish the sigrificance of differences between the two groups. A level of significance of $p<0.05$ was adopted.

\section{Results}

The morphometric parameters in the learning set show many differences between the exfoliated cells from the low grade and the high grade tumours respectively (low grade and high grade), (Table 1).

The results of histomorphometrical classification. histological grade and cytomorphometrical classifica-o tion of the test set are shown in Table 2. There is a good correlation between cytomorphometrical? classification, histomorphometrical classification and established histological grade in each patient.

The histomorphometrical classification results in only one doubtful case (9); histological reexamination of the slides gave no explanation for this. More interesting was case 3. The histomorphometry resulted in a definite low grade classification whereas the cytomorphometry was in accordance with the established histological grade. This case was the only carcinoma-in-situ case in this series. In the cases $6,8,16$, and 19 , there was good correlation between histomorphometry and established histological grade whereas, the cytomorphometrical classification was doubtful. In the remaining cases there was no discrepancy between cytomorphometry, histomorphometry, and established histological grade.

\section{Discussion}

One of the main problems in quantitative studies is to obtain a large reference set of tumours of which the grade is known. This is best ensured if grading is done by several authorities in the field followed by selection of only those cases about which there is a general agreement. Therefore, we organised several sessions where a large number of tumours was graded by several pathologists with special experience in bladder cancer. ${ }^{10}$ Such a procedure is essen- 
tial in validating quantitative studies. The cases in the learning set all belong to this reference material, so that there is minimal doubt about the histological grade of each case. The only case in which there was no agreement between the histomorphometry and the established histological grade was a carcinomain-situ. This is in accordance with our previous study ${ }^{10}$ in which all carcinoma-in-situ cases resulted in a lower grade by histomorphometry. It is not surprising that this carcinoma-in-situ was incorrectly classified since it is known that the superficial cells in carcinoma-in-situ exfoliate easily, whereas the histomorphometrical classification rule used by us $^{10}$ is based on the superficial cell layer. In contrast the cytomorphometrical classification of this carcinomain-situ case resulted in a correct grade.

The fact that the mean nuclear area in the exfoliated cell was largest in the high grade tumours is in agreement with our findings in histological specimen $^{\mathbf{1 0}}$ in which the mean nuclear area of the superficial cell layer was also significantly larger in these tumours. It must be kept in mind that the exact values of histomorphometry and cytomorphometry differ from each other due to difference in processing methods. The results of this study indicate that morphometry of wet-fixed Papanicolaou-stained cells in voided urine of patients with bladder tumours can be of practical value to discriminate patients with low grade and high grade bladder tumours, and that the results of the cytomorphometry correspond very well with the results of histomorphometry and the established histological grade, which is in accordance with the findings of Tribukait $e t$ al, who investigated biopsies from bladder tumours by flow cytomorphometric DNA analysis and compared the results with measurements of exfoliated cells. ${ }^{6} 7$

Especially in the follow-up of patients with transurethrally resected bladder tumours this objective cytological method can be of great value, in the detection of the development of areas of high grade flat carcinomas, from which high grade invasive carcinoma might develop. ${ }^{8}$

If the cytomorphometrical grade is lower than the histomorphometrical grade, a repeat urine specimen should be investigated: in the measured urine of the first sample the diagnostic cells were absent, but might appear in the repeat sample. ${ }^{9}$ Thus cytodiagnosis and histodiagnosis can be used as complementary techniques, as well in objective analyses.

\section{References}

${ }^{1}$ Boon ME, Kurver PHJ, Baak JPA. Ooms ECM. Morphometric differences between urothelial cells in voided urine of patients with grade I and grade II bladder tumours. J Clin Pathol $1981 ; 34: 612-5$.

${ }^{2}$ Soloway MS. Ikard M. Ford K. Cis- diaminedichloroplatinum (II) in locally advanced and metastatic urothelial cancer. Cancer $1981 ; 47: 476-80$.

${ }^{3}$ Matsumoto K. Kakizoe T, Mikuriya S. Tanaka T, Kondo I, Umegaki Y. Clinical evaluation of intraoperative radiotherapy for carcinoma of the urinary bladder. Cancer 1981;47:509-13.

- Cooley WW. Lohnes PR. Multivariate data analysis. New York: John Wiley \& Sons Inc, 1971.

${ }^{5}$ de Voogt HJ. Rothert P, Beyer-Boon ME. Urinary cytology. Berlin. Heidelberg, New York: Springer-Verlag, 1977.

- Tribukait B. Esposti PL. Quantitative flow-microfluorometric analysis of the DNA in cells from neoplasms of the grading and the cytological findings. Urol Res 1978;6:201-5.

${ }^{7}$ Tribukait B, Gustafson H. Esposti P. Ploidy and proliferation in human bladder tumours as measured by flow-cytofluorometric DNA analysis and its relations to histopathology and cytology. Cancer 1979;43:1742-51.

${ }^{8}$ Koss LG. Mapping of the urinary bladder: its impact on the concepts of bladder cancer. Hum Pathol 1979;10:533-48.

๑ Beyer-Boon ME, de Voogt HJ, van der Velde EA, Brussee JAM, Schaberg A. The efficacy of urinary cytology in the detection of uorthelial tumors. Urol Res 1978;6:3-12.

${ }^{10}$ Ooms ECM. Bladder carcinoma: a morphometrical study. Thesis, University of Amsterdam. 1981.

Requests for reprints to: Dr ECM Ooms, Institute of Pathology, Free University Hospital, De Boelelaan 1117, 1007 MB Amsterdam, The Netherlands. 